\title{
Genetic and hormonal aspects of male facilitation of PMSG-induced ovulation in immature mice
}

\author{
H. Ho and J. R. Wilson \\ Institute for Behavioral Genetics, University of Colorado, Boulder, Colorado 80309, U.S.A.
}

\begin{abstract}
Summary. Immature female mice of the SWR/J and $\mathrm{C} 3 \mathrm{H} / \mathrm{Ibg}$ strains pretreated with PMSG showed higher incidence of ovulation when exposed to males of the same strain than did those kept isolated after weaning. Females of the C57BL/6Ibg strain were not affected. The numbers of eggs ovulated were also greater in SWR and $\mathrm{C} 3 \mathrm{H}$ females than in the $\mathrm{C} 57$ females. When SWR/J females were killed after exposure to males for 2,4 or $6 \mathrm{~h}$, there was a 6 -fold increase in LH levels at $6 \mathrm{~h}$ compared to values in isolated controls. It is suggested that adult male mice of some strains provide a stimulus which promotes release of $\mathrm{LH}$ in the immature female.
\end{abstract}

\section{Introduction}

It has been reported previously that male mouse pheromone(s) can influence the reproductive physiology of a female mouse. Male mouse primer pheromones have been shown to synchronize oestrus (Whitten, 1956), block implantation of the zygote (Bruce, 1959), increase the number of eggs released (Zarrow, Christenson \& Eleftheriou, 1971), and accelerate sexual maturation (Vandenbergh, 1969) in the female mouse. All of these primer pheromonal effects have been assumed to occur via olfactory-hypothalamic gonadotrophin pathways (Whitten \& Champlin, 1973). There have been only a few studies which have directly investigated the effect of male pheromones on gonadotrophin release (see Bronson \& Stetson, 1973; Bronson \& Desjardins, 1974; Bronson \& Maruniak, 1976). Bronson \& Desjardins (1974) and Bronson \& Maruniak (1976) found that exposure to males as well as to their urine resulted in immediate elevation of LH values, and the present study was designed to investigate the relationship between this finding and the observation of "male pheromonal facilitation of ovulation in PMSG-primed immature female mice" (Zarrow et al., 1971).

The first experiment replicated the male facilitation of ovulation in PMSG-primed immature female mice and extended this to different strains. The second experiment tested the hypothesis that this effect is mediated by an increase in luteinizing hormone (LH) levels.

\section{Materials and Methods}

\section{Experiment 1}

Animals. Three inbred strains of mice were used: SWR/J breeding pairs were obtained from The Jackson Laboratories, Bar Harbor, Maine, and mice of the $\mathrm{C} 3 \mathrm{H} / 2 \mathrm{Ibg}$ and $\mathrm{C} 57 \mathrm{BL} / 6 \mathrm{Ibg}$ inbred strains were obtained from this Institute. Adult males, to which immature females were exposed, were at least 60 days old and of proven fertility (i.e. had sired litters). Immature female mice were weaned at 21 days of age and caged singly until tested. 
All the animals were maintained and tested within the confines of the SPF laboratory. A $12 \mathrm{~h}$ light-dark cycle was maintained, with lights on from 06:00 to 18:00 h; temperature was $23.3 \pm 1{ }^{\circ} \mathrm{C}$; and relative humidity was $45-55 \%$. Animals were housed in standard stainlesssteel cages. Food (Wayne Sterilizable Lab-Blox) and tap water were provided ad libitum.

Procedures. Since preliminary results indicated that weight was an important factor in PMSG-induced ovulation, only females that weighed at least $7.0 \mathrm{~g}$ at the time of weaning were used. Littermates were paired and matched by weight $( \pm 0.3 \mathrm{~g})$ to control for litter and weight effects, and each member was then assigned to the exposure treatment or control group. At 09:00 $\mathrm{h}$ on the 24th day of age, each immature female was subcutaneously injected with 4 i.u. PMSG in $0.2 \mathrm{ml}$ saline $(9 \mathrm{~g} \mathrm{NaCl} / \mathrm{l})$. On Day 26 of age, at 12:00 h (i.e. $51 \mathrm{~h}$ after the PMSG injection), females in the experimental group were exposed to males of the same strain for the rest of the experiment; the controls remained isolated. The experimental treatment involved transfer of a female to a cage with a $2.5 \mathrm{~cm}$ double wire partition in the centre. The female was housed on the side where an adult male mouse of proven fertility had resided for 2 days, while the male mouse was transferred to the opposite side of the partition. The width of the double wire partition was such that it prevented tactile stimulation between the pair. The fineness of the wire mesh (each square was $3 \mathrm{~mm}^{2}$ ) also reduced visual stimulation. Control mice were transferred to similar cages but no males were used. The experimental and control groups of each strain were housed in separate rooms with separate ventilation systems to eliminate confounding odours.

At 09:00 on Day 27 (i.e. $72 \mathrm{~h}$ after the initial PMSG injection and $21 \mathrm{~h}$ after the start of male exposure), all females were weighed and then killed by cervical dislocation. Oviducts were removed and flushed, and the contents were examined under a dissecting microscope at $\times 40$ magnification for the presence of ova in cumulus cells and for number of ova.

\section{Experiment 2}

Animals. Males and females of the SWR strain were used and were housed exactly as described for Exp. 1.

Procedures. The procedures were the same as those of Exp. 1, except for the times for killing and collection of blood. Since it was not possible to obtain sufficient quantities of blood for radioimmunoassay by sequential sampling, groups of mice were killed by decapitation at 2,4 and $6 \mathrm{~h}$ after the start of exposure to males (i.e. 53, 55 and $57 \mathrm{~h}$ after the PMSG injection). Groups of control mice were killed at the same times. Blood samples were allowed to clot overnight before centrifugation. Serum from each individual was then stored at $-20^{\circ} \mathrm{C}$ until assay.

The radioimmunoassay kit, kindly provided by Dr A. F. Parlow of the NIAMDD Hormone Distribution Program, has been previously examined and validated for assays of mouse $\mathrm{LH}$ (Beamer, Murr \& Geschwind, 1972). The LH does not cross-react with PMSG in the radioimmunoassay (Dr A. F. Parlow, personal communication). The assay was performed by $\mathrm{Dr}$ Gordon Niswender and his staff at Colorado State University, Fort Collins, Colorado. The standard used was NIAMDD-rat-LH-RP1. Sensitivity of the assay was $218.29 \mathrm{pg} / \mathrm{ml}$, and the limit of detection was $44.92 \mathrm{pg} / \mathrm{ml}$.

The data were analysed by $\chi^{2}$, analysis of variance, or the Tukey B tests (Winer, 1971).

\section{Results}

\section{Experiment 1}

Analysis of variance revealed significant strain differences in weight at 27 days of age $(F=$ 188.55, d.f. $=2 / 112, P<0.001)$. The mean \pm s.e.m. weights of the SWR, C3H and C57BL mice when killed were $14.29 \pm 0.09,15.42 \pm 0.15$ and $11.44 \pm 0.18 \mathrm{~g}$, respectively. There was 
no significant difference in body weight between ovulators and non-ovulators. As shown in Table 1 , the proportion of females ovulating in response to exposure to males was greater if they were of the SWR or $\mathrm{C} 3 \mathrm{H}$ strain. There were no strain differences in the occurrence of ovulation in the control groups.

Table 1. Effects of exposure of female mice to males of the same strain on occurrence of ovulation

\begin{tabular}{|c|c|c|c|c|c|c|c|}
\hline \multirow[b]{2}{*}{ Group } & \multicolumn{2}{|c|}{ SWR/J } & \multicolumn{2}{|c|}{$\mathrm{C} 3 \mathrm{H} / 2 \mathrm{Ibg}$} & \multicolumn{2}{|c|}{ C57BL/6Ibg } & \multirow[b]{2}{*}{$\chi^{2}$} \\
\hline & $\begin{array}{l}\text { No. } \\
\text { tested }\end{array}$ & $\begin{array}{c}\text { No. } \\
\text { ovulating (\%) }\end{array}$ & $\begin{array}{l}\text { No. } \\
\text { tested }\end{array}$ & $\begin{array}{c}\text { No. } \\
\text { ovulating (\%) }\end{array}$ & $\begin{array}{l}\text { No. } \\
\text { tested }\end{array}$ & $\begin{array}{c}\text { No. } \\
\text { ovulating (\%) }\end{array}$ & \\
\hline Exposed & 26 & $22(85)$ & 18 & $16(89)$ & 18 & $10(56)$ & $7.05^{*}$ \\
\hline Control & 26 & $11(43)$ & 18 & $9(50)$ & 18 & $9(50)$ & 0.36 \\
\hline$\chi^{2}$ & & $8 \cdot 29^{* *}$ & & $4 \cdot 71^{*}$ & & 0 & \\
\hline
\end{tabular}

Data on the numbers of eggs ovulated were subjected to a two-way analysis of variance (exposure $\times$ strain) which allowed for unequal cell frequencies (Kim \& Kohout, 1975). Females in the experimental groups released almost three times as many ova $(10.06 \pm 1.05)$ as did the control females $(3.39 \pm 0.54)(F=13.82$, d.f. $=1 / 71, P<0.001)$. Strains also differed significantly in ova count. Significantly more ova were released by mice of the SWR $(8.42 \pm 1 \cdot 22)$ and $\mathrm{C} 3 \mathrm{H}(7.69 \pm 1.15)$ strains than by those of the C57BL strain $(3.30 \pm 0.61)(F=8.20$, d.f. $=2 / 71, P<0.001$; Tukey's B test). There was no strain $\times$ exposure interaction.

\section{Experiment 2}

Data on LH levels (see Table 2) were subjected to a two-way (exposure $x$ duration) analysis of variance. Experimental SWR females had significantly higher levels of serum LH than did control females $(96.30 \pm 29.71$ and $15.44 \pm 2.64 \mathrm{ng} / \mathrm{ml}$, respectively; $F=9.06$, d.f. $=1 / 42, P<$ 0.01 ), although the $\mathrm{LH}$ levels were very variable in the exposed females. The time at which the females were killed (i.e. duration of exposure) had an effect on LH concentrations. Values at $14: 00 \mathrm{~h}(18.25 \pm 2.22 \mathrm{ng} / \mathrm{ml})$ were significantly lower $(F=4 \cdot 15$, d.f. $=2 / 42, P<0.05$ (Tukey $B$ test)) than at 18:00 h $(109.10 \pm 33.99 \mathrm{ng} / \mathrm{ml})$. There was also an exposure $\times$ time interaction in that LH levels after exposure to male for $6 \mathrm{~h}$ were increased 6-fold compared to those in control females $(F=3 \cdot 11$, d.f. $=2 / 42, P<0.05)$.

Table 2. Effects on $\mathrm{LH}$ concentrations $(\mathrm{ng} / \mathrm{ml}$ ) observed when $\mathrm{SWR} / \mathrm{J}$ female mice were killed at different times of day after exposure to a male of the same strain at $12: 00 \mathrm{~h}$

\begin{tabular}{lcrr}
\hline & \multicolumn{3}{c}{ Time killed } \\
\cline { 2 - 4 } Group & $14: 00 \mathrm{~h}$ & $16: 00 \mathrm{~h}$ & \multicolumn{1}{c}{$18: 00 \mathrm{~h}$} \\
\hline Exposed & $21.03 \pm 3.27$ & $73.49 \pm 59.99$ & $194.38 \pm 53 \cdot 24$ \\
Control & $15.46 \pm 2.88$ & $7.03 \pm 1.65$ & $23.82 \pm 6.14$ \\
\hline
\end{tabular}

Values are mean \pm s.e.m. for 8 mice at each time for each group.

\section{Discussion}

The results of both experiments confirm previous studies (Zarrow, Estes, Denenberg \& Clark, 1970; Eleftheriou, Bailey \& Zarrow, 1972; Eleftheriou, Christenson \& Zarrow, 1973) that presence of an adult male of proven fertility can facilitate ovulation in an immature, PMSG- 
primed female mouse of the same strain. That this pheromonal effect was obtained only with the $\mathrm{SWR} / \mathrm{J}$ and $\mathrm{C} 3 \mathrm{H} / 2 \mathrm{Ibg}$ strains of mice, and not with the C57BL/6Ibg mice, shows the presence of genetic variance for the pheromonal effect (Zarrow et al., 1971; Eleftheriou et al., 1972). Differences in female or male traits or both may account for the differences among the inbred strains. One explanation may be variation in body weight of females among the inbred strains, since body weight has been shown to be an important predictor of pubertal responsiveness of immature females to male exposure (Bronson \& Desjardins, 1974). The normal relationship between body weight and puberty has not been established for the strains used in the present study. It is possible that the $\mathrm{C} 57 \mathrm{BL} / 6 \mathrm{Ibg}$ females may not have been as responsive to male exposure because they weighed less than did females of the other strains at this age of testing. Although strain differences in response to different doses of PMSG have been reported (Zarrow et al., 1971), it is unlikely that response to PMSG contributed to strain differences in the present study, since control females of the three strains responded similarly with respect to ovulatory behaviour. The occurrence of ovulation in the control females was probably related to $\mathrm{LH}$ contamination of the PMSG (Daniel, 1971) because a second gonadotrophin injection is usually used to induce ovulation after priming with PMSG.

It is more likely that differences in the pheromonal properties of the male account for the observed strain differences. The lack of male pheromonal activity in C57BL mouse strains has been found in other studies (Chipman \& Bronson, 1968; Eleftheriou et al., 1972): e.g. there was facilitation of ovulation when $\mathrm{C} 57 \mathrm{BL} / 6 \mathrm{~J}$ females were exposed to $\mathrm{SWR} / \mathrm{J}$ males but no facilitation occurred when SWR/J females were exposed to C57BL/6J males (Eleftheriou et al., 1972). Some C57BL strains are testosterone-deficient (Bartke, 1974). Since several pheromonal effects have been found to be androgen-dependent (Whitten, 1966; Bronson \& Whitten, 1968; Bruce, 1970; Eleftheriou et al., 1973; Vandenbergh, 1975), this could be the reason why C57BL/6Ibg males did not facilitate the occurrence of ovulation in females of the same strain or increase the number of ova released by females which did ovulate.

The results of Exp. 1 therefore support previous findings that male presence (presumably male pheromones) can facilitate PMSG-induced ovulation in immature females and that there are strain differences in facilitation.

Mice of the SWR/J strain were used in Exp. 2 because the difference between the experimental and control females of that strain was greatest in Exp. 1, the LH levels after $6 \mathrm{~h}$ of male exposure being 6-fold greater than in control females. The variable LH levels of the exposed females were probably due to individual differences in responsiveness. When tactile stimulation was allowed, Bronson \& Desjardins (1974) found a 4- to 5-fold increase in serum LH after 1-3 h of male exposure in young females experiencing a precocious puberty. Bronson \& Maruniak (1976) found that exposure to male urine resulted in elevation of serum LH within 30 min.

Although the increased $\mathrm{LH}$ concentrations can account for the increase in occurrence of ovulation, it is uncertain whether the higher ovulation number is also a consequence. The male may also stimulate the release of FSH, which increases recruitment to the population of mature follicles. It is clear that male stimuli act directly on the secretion of $\mathrm{LH}$, presumably by central stimulation of the hypothalamus, leading to release of $\mathrm{LH}-\mathrm{RH}$.

We thank M. K. Watson, Institute for Behavioral Genetics, for valuable technical assistance: Dr G. Niswender and staff for the radioimmunoassays; and Dr A. Parlow for the necessary reagents. This research was supported by NIMH Training Grant MH-11167 to Dr Gerald E. McClearn.

\section{References}

Bartke, A. (1974) Increased sensitivity of seminal vesicles to testosterone in a mouse strain with low plasma testosterone levels. J. Endocr. 60, 145-148.
Beamer, W.G., Murr, S.M. \& Geschwind, I.I. (1972) Radioimmunoassay of mouse luteinizing and follicle stimulating hormone. Endocrinology 90, 823-827. 
Bronson, F.H. \& Desjardins, C. (1974) Circulatory concentrations of FSH, LH, estradiol, and progesterone associated with acute, male-induced puberty in female mice. Endocrinology 94, 16581668.

Bronson, F.H. \& Maruniak, J.A. (1976) Differential effects of male stimuli on follicle-stimulating hormone, luteinizing hormone, and prolactin secretion in prepubertal female mice. Endocrinology 98, 11011108.

Bronson, F.H. \& Stetson, M.H. (1973) Gonadotropin release in prepubertal female mice following maleexposure: a comparison with the adult cycle. Biol. Reprod. 9, 449-459.

Bronson, F.H. \& Whitten, W. (1968) Oestrusacceleration pheromones of mice: assay, androgen dependency and presence in bladder urine. J. Reprod. Fert. 15, 131-134.

Bruce, H.M. (1959) An exteroceptive block to pregnancy in the mouse. Nature, Lond. 184, 105.

Bruce, H.M. (1970) Pheromones. Br. med. Bull. 26, 1013.

Chipman, R.K. \& Bronson, F.H. (1968) Pregnancy blocking capacity and inbreeding in laboratory mice. Experientia 24, 199-200.

Daniel, J.C. (1971) Methods in Mammalian Embryology. W. H. Freeman and Co., San Francisco.

Eleftheriou, B.E., Bailey, D.W. \& Zarrow, M.X. (1972) A gene controlling male pheromonal facilitation of PMSG-induced ovulation in mice. J. Reprod. Fert. $31,155-158$.

Eleftheriou, B.E., Christenson, C.M. \& Zarrow, M.X. (1973) The influence of exteroceptive stimuli and pheromonal facilitation of ovulation in different strains of mice. J. Endocr. 57, 363-370.

Kim, J.O. \& Kohout, F.J. (1975) Analysis of variance and covariance: subprograms. In Statistical Package for Social Sciences, pp. 398-433. Eds N. H. Nie, C. H. Hull, J. G. Jenkins, K. Steinbrenner \& D. H. Bent. McGraw-Hill Book Co., New York.

Vandenbergh, J.G. (1969) Male odor accelerates female sexual maturation in mice. Endocrinology 81, 345249.

Vandenbergh, J.G. (1975) Partial isolation of a pheromone accelerating puberty in female mice. $J$. Reprod. Fert. 43, 515-523.

Whitten, W.K. (1956) Modification of the oestrous cycle of the mouse by external stimuli associated with the male. J. Endocr. 13, 399-404.

Whitten, W.K. (1966) Pheromones and mammalian reproduction. Adv. Reprod. Physiol. 1, 155-177.

Whitten, W.K. \& Champlin, A.K. (1973) The role of olfaction in mammalian reproduction. In Handbook of Physiology, Sec. F, Endocrinology, Vol. 2, Part 1, pp. 109-123. Ed. R. O. Greep. American Physiological Society, Washington, D.C.

Winer, B. (1971) Statistical Principles in Experimental Design. McGraw-Hill Book Co., New York.

Zarrow, M.X., Estes, S.A., Denenberg, V.H. \& Clark, J.H. (1970) Pheromonal facilitation of ovulation in the immature mouse. J. Reprod. Fert. 23, 357-360

Zarrow, M.X., Christenson, C.M. \& Eleftheriou, B.E. (1971) Strain differences in ovulatory response of immature mice to PMS and to pheromonal facilitation of PMS-induced ovulation. Biol. Reprod. $4,52-56$.

Received 4 September 1979 